\title{
ПІЛОТНИЙ ПРОЕКТ РЕФОРМУВАННЯ СИСТЕМИ ОХОРОНИ ЗДОРОВ'Я (ЗАСТОСУВАННЯ ЕЛЕМЕНТІВ ПРОГРАМНО- ЦІЛЬОВОГО МЕТОДУ, ПЕРЕХІД ДО СТРАТЕГІЧНИХ ЗАКУПІВЕЛЬ)
}

\author{
${ }^{1}$ ДНУ “Науково-практичний центр профілактичної та клінічної медицини” Державного управління \\ справами, м. Київ, Україна \\ ${ }^{2}$ Ужгородський національний університет, Україна
}

\begin{abstract}
Мета: оцінка запровадження нових фінансово-економічних механізмів у пілотних регіонах (Вінницька, Дніпропетровська, Донецька області та м. Київ).

Матеріали і методи. Проаналізовано нормативно-правову базу. Використано аналітичний та порівняльний методи. Оцінка виконання бюджетних програм “Первинна медична допомога" у 2013 р. проведена за удосконаленою Методикою здійснення порівняльного аналізу ефективності бюджетних програм, які виконуються розпорядниками місцевих бюджетів

Результати. Видатки на ПМД у Вінницькій області склали 22,4\% зведеного бюджету на охорону здоров'я, у Дніпропетровській - 18,53\%, у Донецькій - 17,8\%, у м. Києві - 13,6\%. Продовжує зростати частка видатків на фінансування екстреної медичної допомоги за функцією "Станції швидкої та невідкладної допомоги" до 5,1\%. Виконання бюджетних програм “Первинна медична допомога” у 2013 р. оцінюється у Дніпропетровській області як високе (225 балів), Вінницькій - як низьке (106 балів).

Висновки. Фінансування за видами медичної допомоги на рівні місцевих бюджетів можна оцінити позитивно. Відпрацювання механізму стратегічних закупівель на рівні ПМД вдалося завдяки здійсненню організаційнофункціонального та фінансового виділення саме цього виду медичної допомоги.
\end{abstract}

КЛЮЧОВІ СЛОВА: бюджетна програма, стратегічні закупівлі, комунальні некомерційні підприємства.

У рамках проведення реформування системи охорони здоров'я у пілотних регіонах (Вінницька, Дніпропетровська, Донецька області та місто Київ) запропоновано відпрацювати застосування елементів програмно-цільового методу у бюджетному процесі на рівні місцевих бюджетів у частині видатків на охорону здоров'я за відповідними видами медичної допомоги, фінансове забезпечення закладів охорони здоров'я (303) за видами медичної допомоги відповідно до договорів про медичне обслуговування населення [4]. Запровадження цих новацій на рівні пілотних регіонів підтверджено найкращими світовими практиками та науковими дослідженнями.

Як показує світовий досвід, уряди всіх країн світу постійно працюють над пошуком нових та кращих методик формування бюджету, розпорядження бюджетними ресурсами і використання коштів платників податків. У різних країнах в певних історичних умовах широко використовувалася політика дефіцитного фінансування, що ґрунтувалася на кейнсіанських засадах.

у сучасних умовах розвитку економіки та суспільства в багатьох країнах запроваджується

(C) М.В. Шевченко, Г.О. Слабкий, 2014 ідеологія управління фінансами, близька до підприємницької шкали цінностей, яка вважається еталоном раціональності рішень. Створений у такий спосіб бюджет не тільки відображає у вартісному еквіваленті масштаби діяльності, але й, водночас, обмежує їі певною сумою видатків, використовуючи різні інструменти для стримування їх зростання. Контроль величини видатків неможливий без ефективних новітніх управлінських заходів і технологій, орієнтованих на кінцевий результат. Відомі різні види цієї технології, яка переносить наголос з управління бюджетними ресурсами на управління бюджетними результатами, забезпечує більшу транспарентність бюджету, кращий розподіл бюджетних коштів: «бюджетування, спрямоване на результати», «управління/покращення продуктивністю». Цей метод передбачає розроблення та реалізацію бюджетних програм, орієнтованих на кінцевий результат (згідно зі стратегічними цілями), із застосуванням критеріїв оцінки їх результативності та ефективності використання бюджетних коштів $[1 ; 3 ; 6 ; 8]$.

Також запровадження проспективної оплати постачальників медичної допомоги на основі кон- 
трактів (договорів), як одного із заходів поліпшення справедливості та ефективності системи фінансування, сприяє збільшенню залучення ресурсів у країнах із середніми рівнями доходів (рекомендації у рамках стратегії економічного розвитку Комісії з макроекономіки і здоров'я (The Commission on Macroeconomics and Health) [9].

У Доповіді про стан здоров'я у світі “Финансирование систем здравоохранения. Путь к всеобщему охвату населения медико-санитарной помощью" (2010) [2] наголошується, що в системах охорони здоров'я, передусім Європейського регіону, спостерігається тенденція до використання стратегічних ("активних") закупівель як механізму фінансування надавачів медичних послуг для забезпечення найкращих результатів 3 точки зору покращення здоров'я населення. Механізми укладання контрактів (договорів) і оплати на основі обсягів та якості наданих послуг - центральні елементи ефективної системи закупівель медичних послуг.

За даними досліджень, більш активні закупівлі (коли розмежовані функції покупця і надавача) можуть покращити якість та ефективність систем охорони здоров'я за рахунок врахування потреб населення в медичній допомозі, регіональних відмінностей, втручань і послуг, які найбільше відповідають потребам і очікуванням населення, обсягів наявних ресурсів, механізмів їх закупівлі, включаючи контрактні механізми і системи оплати надавачів [5;10].

Важливим є також вибір методу оплати постачальників медичних послуг. На сьогодні в Україні цей процес представляє виділення бюджетних коштів безпосередньо постачальникам (так звані «пасивні» закупівлі), функції фінансуючої сторони і надавачів не розмежовані [8].

Метою даного дослідження була оцінка запровадження нових фінансово-економічних механізмів у пілотних регіонах, зокрема застосування елементів програмно-цільового методу у бюджетному процесі на рівні місцевих бюджетів у частині видатків на охорону здоров'я за відповідними видами медичної допомоги, фінансове забезпечення закладів охорони здоров'я за видами медичної допомоги відповідно до договорів про медичне обслуговування населення та можливість поширення набутого досвіду на систему охорони здоров'я в Україні.

Матеріали і методи. У процесі проведення дослідження було використано аналітичний, порівняльний методи на основі аналізу положень відповідних нормативно-правових актів, якими врегульовувалися питання запровадження відповідних механізмів. Оцінка виконання бюджетних програм “Первинна медична допомога” у 2013 р. проведена за удосконаленою методикою здійснення порівняльного аналізу ефективності бюджетних програм, які виконуються розпорядниками місцевих бюджетів, розробленою Міністерством фінансів України спільно з Інститутом бюджету та соціально-економічних досліджень (зі змінами) на прикладі Дніпропетровської та Вінницької областей [10].

Результати дослідження та їх обговорення. Розроблено низку нормативних актів, які регулюють застосування елементів програмноцільового методу у бюджетному процесі на рівні місцевих бюджетів. Зокрема спільним наказом Міністерства фінансів та Міністерства охорони здоров'я України від 25.07.2013 № 693/633 «Про затвердження Змін до Типового переліку бюджетних програм та результативних показників їх виконання для місцевих бюджетів у галузі «Охорона здоров'я»» внесено зміни до Типового переліку бюджетних програм та результативних показників їх виконання для місцевих бюджетів у галузі «Охорона здоров'я».

Наказом Міністерства охорони здоров'я України від 08.06.2011 № 347 «Про затвердження Тимчасового типового переліку бюджетних програм та результативних показників їх виконання для місцевих бюджетів у галузі «Охорона здоров'я» для пілотних проектів у Вінницькій, Дніпропетровській, Донецькій областях та м. Києві» затверджено Типовий перелік бюджетних програм та результативні показники їх виконання.

Наказом Міністерства фінансів України від 14.01.2011 №11 «Про бюджетну класифікацію» затверджено функціональну класифікацію видатків та кредитування бюджету, в якій виділено окремі функції щодо центрів екстреної медичної допомоги та медицини катастроф, станцій екстреної (швидкої) медичної допомоги (код 0724), центрів первинної медичної (медико-санітарної) допомоги (код 0726), перинатальних центрів (код 0733), що дозволяє визначити обсяги фінансування на надання медичної допомоги саме в цих типах закладів.

Виділення окремої функції «Центри первинної медичної (медико-санітарної допомоги)» у функціональній класифікації видатків і кредитування бюджету дає змогу простежувати дані про обсяги видатків на надання ПМД у центрах ПМСД. У цілому видатки на їх фінансування в країні становили 8,09\% від загального обсягу фінансування охорони здоров'я з місцевих бюджетів і практично вдвічі зросли порівняно з 2012 р. (4,33\%).

Якщо враховувати розмежування фінансування надання первинної та вторинної медичної допомоги у пілотних регіонах, то можна стверджувати, що на фінансування надання тільки ПМД у Вінницькій області спрямовано 22,4\% зведеного бюджету області на охорону здоров'я (2012 р. 21,96\%), у Дніпропетровській та Донецькій відповідно 18,53\% (2012 р. - 17,96\%) та 17,8\% 
(16,81\%). У м. Києві частка видатків на їх фінансування у зведеному бюджеті міста на охорону здоров'я склала 13,6\%.

Продовжує зростати частка видатків у зведеному бюджеті областей на фінансування екстреної медичної допомоги за функцією «Станції швидкої та невідкладної допомоги» до 5,1\% (2012 р. 3,43\%; 2011 р. - 2,7\%). Це пов'язано з продовженням реформування системи екстреної медичної допомоги та реорганізацією 303 та їхніх структурних одиниць.

Оцінка виконання бюджетних програм «Первинна медична допомога» у 2013 р., проведена за методикою здійснення порівняльного аналізу ефективності бюджетних програм, засвідчила, що загальну ефективність бюджетної програми «Первинна медична допомога населенню» за 2013 р. у Дніпропетровській області можна оцінити як високу (225 балів), оскільки її показник знаходиться в діапазоні 215 і більше балів (для порівняння: ефективність бюджетної програми «Первинна медична допомога населенню» за 2012 р. було оцінено як середню, оскільки її показник становив 200 балів і знаходився в діапазоні 190-215 балів). У Вінницькій - як низьку (106 балів), оскільки її показник менше 190 балів (для порівняння: ефективність бюджетної програми «Первинна медична допомога населенню» за 2012 р. було оцінено як середню, оскільки ії показник становив 198,53 бала і знаходився в діапазоні 190-215 балів). Це було пов'язано 3 недофінансуванням видатків на придбання обладнання та проведення ремонтних робіт, що, в свою чергу, вплинуло і на величину показників продукту - кількості закупленого обладнання та відремонтованих об'єктів.

За даними виконання паспортів бюджетних програм у 2013 р. загальну ефективність бюджетної програми «Первинна медична допомога населенню» у Дніпропетровській області можна оцінити як високу з урахуванням показників ії виконання у 2012 р.

Загальну ефективність бюджетної програми «Первинна медична допомога населеннюз за 2013 р. у Вінницькій області оцінено як низьку, оскільки це було пов'язано з недофінансуванням видатків на придбання обладнання та проведення ремонтних робіт, а також відсутністю показників якості за двома завданнями цієї програми, що негативно вплинуло на ефективність виконання бюджетної програми.

Аналіз використання бюджетних коштів у розрізі відповідних програм за видами надання медичної допомоги, зокрема вторинну медичну допомогу (ВМД), не вдалося провести у зв'язку з гальмуванням організаційно-функціональних змін відповідних 303, які надавали ВМД.
Щодо впровадження механізму фінансового забезпечення закладів охорони здоров'я у пілотних регіонах за видами медичної допомоги на підставі договорів про медичне обслуговування населення, то можна відзначити, що положення Закону [1] було виконано тільки частково, на рівні 303, що надавали ПМД. Хоча опрацьовано підходи до запровадження укладення договорів про медичне обслуговування населення на рівні 303, які надають й інші види медичної допомоги (наказ МОЗ України від 01.11.2011 № 742 «Про затвердження примірного договору про медичне обслуговування населення» (зі змінами від 28.12.2011 № 992)).

Запровадження стратегічних закупівель тісно пов'язане і з питанням зміни господарського статусу 303, що надають ПМД, з бюджетних установ на комунальні некомерційні підприємства або комунальні некомерційні установи.

Цей механізм було відпрацьовано в м. Києві, де всі центри ПМСД були реорганізовані у комунальні некомерційні підприємства. В органах державної податкової служби ці підприємства зареєстровані як неприбуткові організації. Однак в ході пілотування не вдалося вирішити питання щодо поширення цього досвіду на всю територію держави. Комунальні некомерційні підприємства є правонаступниками прав та обов'язків амбулаторно-поліклінічних закладів, здійснюють ті самі функції та провадять господарську некомерційну діяльність, спрямовану на досягнення економічних, соціальних та інших результатів без мети одержання прибутку. Водночас вони не підпадають під визначення бюджетної установи, оскільки є одержувачами бюджетних коштів. У результаті з втратою статусу бюджетної установи у таких закладах, створених у формі комунальних некомерційних підприємств, виникли проблеми з оподаткуванням, а також з оплатою комунальних послуг, енергоносіїв тощо.

\section{Висновки}

1. У цілому використання елементів програмно-цільового методу у бюджетному процесі на рівні місцевих бюджетів у частині видатків на охорону здоров'я можна оцінити позитивно. При цьому необхідно в подальшому забезпечити чіткий зв'язок договорів з програмно-цільовим методом планування бюджетів 303 та враховувати передбачені відповідно до цього методу індикатори витрат, продуктивності, якості та ефективності діяльності, крім того необхідно більш детально виписувати кількісні та якісні показники.

2. Відпрацювання механізму стратегічних закупівель на рівні ПМД вдалося завдяки здійсненню організаційно-функціонального та фінансового виділення саме цього виду медичної допомоги. 
3. Вирішення питання щодо особливостей оподаткування 303, створених у формі комунальних некомерційних підприємств, можливе шляхом внесення змін до Податкового кодексу України.
Перспективи подальших досліджень полягають у подальшому супроводі поширення позитивного досвіду системи фінансування охорони здоров'я в Україні та розробки пропозицій щодо їх нівелювання.

\section{Список літератури}

1. Важнейшие задачи систем здравоохранения в периоды финансовых кризисов. Европейский региональный комитет. Шестьдесят вторая сессия. Мальта, 10-13 сент. 2012. - 4 с.

2. Доклад о состоянии здравоохранения в мире. Финансирование систем здравоохранения. Путь к всеобщему охвату населения медико-санитарной помощью. Всемирная организация здравоохранения, 2010. - С. 1-106.

3. Кульчицький М. І. Програмно-цільове бюджетування на місцевому рівні / М. І. Кульчицький, С. Н. Самец [Електронний ресурс] // Ефективна економіка. - 2012. - № 8. - Режим доступу : http://www.economy.nayka.com.ua/ ?ор $=1 \& z=1269$. - Назва з екрану.

4. Про порядок проведення реформування системи охорони здоров'я у Вінницькій, Дніпропетровській, Донецькій областях та місті Києві : Закон України від 07.07.2011 № 3612-VI // ВВР України. - 2012. - № 12 (№ 12-13). С. 552.

5. Проект программного бюджета на 2004-2005 гг.: Перспектива Европейского Региона ВОЗ. Европейский региональный комитет. Пятьдесят вторая сессия. Копенгаген, 16-19 сент. 2002. - 18 с.

6. Просяник Н. В. Реалізація програмно-цільового методу бюджетування на місцевому рівні / Н. В. Просяник // Наукові праці Кіровоградського національного технічного університету. Економічні науки. - 2012. - Вип. 22, ч. II. - С. 1-5.

7. Удосконалена Методика здійснення порівняльного аналізу ефективності бюджетних програм, які виконуються розпорядниками коштів місцевих бюджетів : лист Міністерства фінансів України від 19.09.2013 року № 31-05110-14-5/27486 [Електронний документ]. - Режим доступу : http://www.ibser.org.ua/news/595/- Нaзва з екрану.

8. Федосов В. Конспект лекцій на тему "Бюджет" [Електронний ресурс] / В. Федосов, С. Юрій. - Режим доступу : http://pidruchniki.com/1228112846046/ekonomika/programno-tsilove_byudzhetuvannya_ problemi_stanovlennya_rozvitku. - Назва з екрану.

9. Investing in health. A Summary of the Findings of the Commission on Macroeconomics and Health. World Health Organization. - Geneva, 2013. - P. 17.

10. Public ends, private means. Strategic purchasing of health services: strategic purchasing of value for money in health care / Preker A. S. [et al.]. - Washington, DC, The World Bank, 2007.

\section{ПИЛОТНЫЙ ПРОЕКТ РЕФОРМИРОВАНИЯ СИСТЕМЫ ЗДРАВООХРАНЕНИЯ (ПРИМЕНЕНИЕ ЭЛЕМЕНТОВ ПРОГРАММНО-ЦЕЛЕВОГО МЕТОДА, ПЕРЕХОД К СТРАТЕГИЧЕСКИМ ЗАКУПКАМ)}

М.В. Шевченко ${ }^{1}$, Г.А.Слабкий

${ }^{1}$ ГНУ “Научно-практический центр профилактической и клинической медицины” Государственного управления делами, г. Киев, Украина

2Ужгородский национальный университет, Украина

Цель: оценка внедрения новых финансово-экономических механизмов в пилотных регионах (Винницкая, Днепропетровская, Донецкая области и г. Киев).

Материалы и методы. Проанализирована нормативно-правовая база. Использованы аналитический и сравнительный методы. Оценка выполнения бюджетных программ "Первичная медицинская помощь" в 2013 г. проведена по усовершенствованной Методике осуществеления сравнительного анализа эффективности бюджетных программ, которые выполняются распорядителями местных бюджетов.

Результаты. Расходы на ПМП в Винницкой области составили 22,4\% консолидированного бюджета на здравоохранение, в Днепропетровской - 18,53\%, в Донецкой - 17,8\%, в г. Киеве - 13,6\%. Продолжает возрастать часть расходов на финансирование экстренной медпомощи за функцией "Станции быстрой и неотложной помощи" до 5,1\%. Выполнение бюджетных программ “Первичная медпомощь” в 2013 г. оценивается в Днепропетровской области как высокое (225 баллов), в Винницкой - как низкое (106 баллов).

Выводы. Финансирование по видам медпомощи на уровне местных бюджетов в части расходов на здравоохранение можно оценить положительно. Отработка механизма стратегических закупок на уровне ПМП стала возможной благодаря организационно-функциональному и финансовому выделению именно этого вида медпомощи.

КЛЮЧЕВЫЕ СЛОВА: бюджетная программа, стратегические закупки, коммунальные некоммерческие предприятия. 


\section{PILOT PROJECT OF HEALTH CARE SYSTEM REFORMING (APPLICATION OF ELEMENTS OF PROGRAM-TARGET METHOD, TRANSITION TO STRATEGIC PURCHASES)}

M.V. Shevchenko', G.O. Slabkyi

${ }^{1}$ State Scientific Institution "Scientific-Practical Center of Clinical and Preventive Medicine" the State Administration, Kyiv, Ukraine

${ }^{2}$ Uzhhorod National University, Ukraine

Purpose: estimation of introduction of new financial and economic mechanisms in pilot regions (Vinnytsia, Dnipropetrovsk, Donetsk region and Kyiv).

Materials and methods. The regulatory framework has been analyzed. Analytical and comparative methods are used. Evaluation of budgetary programs performance "Primary health care" in 2013 is spent by an advanced Technique of comparative analysis of efficiency of budgetary programs, which are carried out by managers of local budgets.

Results. Expenses on PHC in Vinnitsia region were 22.4\% of the consolidated budget on public health care, in Dnipropetrovsk - $18.53 \%$, in Donetsk - $17.8 \%$, in Kyiv - 13.6\%. The share of expenses on financing of emergency medical care on function "Station of the fast and urgent aid" to $5.1 \%$ continues to increase. Performance of budgetary programs "Primary health care" in 2013 is estimated in Dnipropetrovsk region as high (225 points), Vinnitsia - as low (106 points).

Conclusions. Financing by type of health care at level of local budgets can be evaluated positively. Working off mechanism of strategic purchases at PHC level was possible due to implementation of organizational, functional and financial allocation of this type of health care.

KEY WORDS: budgetary program, strategic purchases, public noncommercial enterprises.

Рукопис надійшов до редакції 08.11.2014 р.

\section{Відомості про авторів:}

Шевченко Марина Вікторівна - к.мед.н., с.н.с. наукового відділу організації медичної допомоги Дну “Науково-практичний центр профілактичної та клінічної медицини" Державного управління справами; тел.: +38 (044)254-68-71.

Слабкий Геннадій Олексійович - д.мед.н., проф. кафедри громадського здоров'я Ужгородського національного університету. E-mail: g.slabkiy@mail.ru. 